\title{
Attitudes Towards Environmental and Agronomic Benefits of Pulses Among Canadian University Students
}

\author{
Kristie Masuda \\ University of Lethbridge \\ 4401 University Drive, Lethbridge, Alberta, Canada \\ Email: kristie.masuda@uleth.ca
}

Received: August 1,2018 Accepted: August 17, 2018

doi:10.5296/jas.v6i3.13710 URL: https://doi.org/10.5296/jas.v6i3.13710

\begin{abstract}
An increase in the production and consumption of pulse crops has the potential to improve soil health, decrease greenhouse gas emissions, and mitigate climate change. University students in Canada were surveyed to reveal attitudes and opinions towards the environmental and agronomic benefits of pulse production and consumption in an attempt to determine motivations towards pulse consumption. Results indicated that participants would be more likely to consume pulses because they reduce greenhouse gases $(67 \%)$, improve soil health and reduce the need for fertilisers $(71 \%)$, and contribute to sustainable agriculture $(71 \%)$.
\end{abstract}

Keywords: pulses, pulse crops, beans, lentils, legumes, university students, Canada, environment

\section{Introduction}

\subsection{Agronomic Benefits of Pulses}

Pulses are the edible seeds that are harvested from pods of annual leguminous plants. The most commonly grown pulse crops in Canada are chickpeas (Cicer arietinum), lentils (Lens culinaris), dry beans (primarily Phaseolus vulgaris), and dry peas (Pisum sativum) (Tosh and Yada 2010). Pulse crop production within Canada can be partially attributed to the agronomic benefits of growing pulses, particularly due to their ability to fix nitrogen from the air. Working together with rhizobia bacteria, which are found in soils of many natural ecosystems, pulse crops convert atmospheric nitrogen into nitrogen compounds that can be used by plants. This improves soil fertility and reduces dependency on synthetic fertilisers. This favourable process has likely resulted in more farmers incorporating pulses into their crop rotations. 
Not only do pulse crops contribute to transferring nitrogen from the air into the soil, but they also improve residual soil water and significantly enhance system productivity in rain fed dry areas (Gan et al. 2017). Additionally, pulse crops stimulate the productivity of the crops that follow (Jensen et al. 2012). Spring wheat harvested from fields following pulse crops averaged higher yields and protein content than other rotations, even when the same amount of nitrogen was made available for the different crops (Miller et al. 2002). Further, instead of fallowing, farmers can plant grain crops after pulse crops to reduce soil degradation and benefit from the income gained from the pulse harvest (Carlyle 2004). These factors combine to make pulses a compelling economic benefit to successful agricultural practices.

\subsection{Pulses and Climate Change}

It has been estimated that Canada's agricultural sector is responsible for approximately $8 \%$ of all greenhouse gas emissions in the country (Gan et al. 2011). As pulse plants fix atmospheric nitrogen in the soil, they do not need nitrogen fertilisers, thereby reducing greenhouse gas emissions. For example, a study in Saskatchewan found that durum crop preceded by lentils or chickpeas the previous year decreased its carbon footprint by $17 \%$ compared to durum preceded by cereal crops (Gan et al. 2011).

The role of carbon dioxide in anthropogenic climate change has resulted in both consumers and food product manufacturers searching for new products with functional and nutritional benefits that have reduced carbon footprints (Boye, Zare, and Pletch 2010). Crop rotations containing pulses have lower carbon dioxide emissions compared with non-pulse crops (Lemke et al. 2007). Replacing cereal crops with pulse crops has also been shown to reduce overall carbon dioxide emissions related to energy inputs (Lemke et al. 2007). In addition, pulse crops do not require as much water as other crops (Angadi et al. 2008). Due to anthropogenic climate change, it is likely that there will be less water available for agriculture in some regions. These factors could make increasing the production of pulses appealing to consumers, farmers, and food product manufacturers.

Increasing the prevalence of pulse crops could also bring about several other positive environmental changes. Pulse crops enhance soil fertility and reduce greenhouse gas emissions and land clearing as they fix between 70 to $90 \%$ of their nitrogen from the air and the rest from the soil (Carlyle 2004). The decrease in emissions resulting from pulse farming could potentially lead to a decrease in global warming, as nitrogen fertilisation is responsible for half of all greenhouse gas emissions within the agricultural sector (Magrini et al. 2016). In addition, pulse crops can be grown in marginal or degraded lands (Jensen et al. 2012), which can be beneficial in areas that do not have access to adequate water supplies. This makes pulse crops an environmentally favourable solution to mitigating climate change, which is becoming increasingly important as global populations increase and sustainability becomes paramount.

\subsection{Plant-Based Proteins}

There is a strong relationship between diet and environmental sustainability, and foods can have significantly different environmental impacts (Tilman and Clark 2014). Greenhouse gas 
emissions are strongly influenced by dietary composition, with plant-based foods producing lower greenhouse gas emissions than animal-based foods (Tilman and Clark 2014). Consumption of plant proteins is more environmentally beneficial to consuming meat protein because meat has an inherently inefficient conversion, with six kilograms of plant protein being required to produce one kilogram of meat protein (Pimentel and Pimentel 2003). Chickpeas and lentils contain $22 \%$ and $26 \%$ protein (dry weight), respectively, with slight variances based on growing condition, plant species, maturity, and variety (Pulse Canada n.d.). This compares to $23 \%$ protein for lean ground chicken and $26 \%$ protein for medium ground beef (Health Canada n.d.). This similarity in protein content is relevant because if consumers are more aware of the impacts that meat consumption has on the environment, they may be more likely to increase their consumption of pulses to fulfill their nutritional requirements. With the increased attention on climate change and environmental sustainability, the fact that meat contributes to higher production of greenhouse gases and carbon dioxide emissions than vegetable products has increased advocacy in reducing the consumption of protein from animal sources.

\section{Methods}

\subsection{Sample Population}

Despite the obvious benefits to producing and eating pulses, pulse consumption among Canadians is relatively low, with just $13 \%$ of the population consuming pulses daily (Ramdath, Renwick, and Duncan 2016). Barriers to pulse consumption have been somewhat explored in the general Canadian population (Ipsos Reid 2010; Froehlich Chow et al. 2015; Phillips et al. 2015), and this study continued the exploration of factors influencing pulse consumption by focusing exclusively on university students.

University students were the target population in the study because concern over environmental issues has been increasing, and research supports the assumption that there is an increasing concern about the environment amongst university students (Cortes et al. 2016). It is possible that increased knowledge of the environmental significance of pulse crops could motivate students to adopt dietary changes, which could ultimately assist in mitigating the current food system's environmental impact.

The population for this online study was drawn from students attending the University of Lethbridge, of which there were 8,558 in the fall term of 2017 (University of Lethbridge 2017). This study sought participants specifically from this university because many pulse crops are grown in and around this area. The sample population included full- or part-time students aged 18 years or older currently attending the University of Lethbridge. Convenience sampling and snowball sampling were used to recruit participants. 


\subsection{Design}

A cross-sectional online survey was used to collect the data. The survey was built using Qualtrics Research Suite, which is a Web-based platform used for creating and conducting online surveys. It was hoped that it would be possible to identify characteristics and factors contributing to differences in pulse consumption levels using the Likert scales and categorical scales that were used for most of the questions. All participants were given the opportunity to enter to win one of three $\$ 50$ cash prizes.

The study was approved by the University of Lethbridge Human Subjects Research Ethics Board in November 2017. The collection of data took place over a three-week period in November and December of 2017.

\section{Results and Discussion}

Environmentally sustainable agricultural practices did not appear to strongly influence participants' food purchasing practices, with 30\% neither agreeing nor disagreeing with the statement that they influence food purchases (see Table 1). The majority of respondents (71\%) agreed that it is important to eat locally grown foods, and $62 \%$ are trying to choose plant-based options more often.

Table 1. Weighted Percentages of Level of Agreement About Knowledge and Attitudes Towards Pulses Regarding Plant-Based, Locally Grown Foods, and Environmental Responsibility

\begin{tabular}{l|c|c|c|c|c}
\hline & $\begin{array}{l}\text { Strongly } \\
\text { disagree }\end{array}$ & $\begin{array}{c}\text { Some-what } \\
\text { disagree }\end{array}$ & $\begin{array}{c}\text { Neither } \\
\text { agree nor } \\
\text { disagree }\end{array}$ & $\begin{array}{c}\text { Some-what } \\
\text { agree }\end{array}$ & $\begin{array}{c}\text { Strongly } \\
\text { agree }\end{array}$ \\
\hline $\begin{array}{l}\text { I am trying to choose plant-based } \\
\text { options more often }\end{array}$ & 6.35 & 16.67 & 14.68 & 41.67 & 20.63 \\
\hline $\begin{array}{l}\text { It is important to eat locally grown } \\
\text { foods }\end{array}$ & 2.79 & 5.58 & 20.32 & 43.82 & 27.49 \\
\hline $\begin{array}{l}\text { Environmentally sustainable } \\
\text { agricultural practices influence my } \\
\text { food purchases }\end{array}$ & 10.67 & 20.72 & 29.88 & 28.29 & 10.36 \\
\hline $\begin{array}{l}\text { I advocate for the protection and } \\
\text { responsible use of the natural } \\
\text { environment }\end{array}$ & & & & & \\
\hline
\end{tabular}

Sixty-seven per cent of participants would be more likely to consume pulses because pulse crops reduce greenhouse gases, $71 \%$ would be more likely to consume pulses because they improve soil health and reduce the need for fertilisers, and $71 \%$ also would be more likely to consume pulses because they contribute to sustainable agriculture (see Table 2). 
Table 2. Weighted Percentages of How Likely Knowledge of Environmental Characteristics of Pulses Affects Their Consumption

\begin{tabular}{l|c|c|c|c|c}
\hline & $\begin{array}{c}\text { Much less } \\
\text { likely }\end{array}$ & $\begin{array}{c}\text { Somewhat less } \\
\text { likely }\end{array}$ & $\begin{array}{c}\text { Would make } \\
\text { no difference }\end{array}$ & $\begin{array}{c}\text { Somewhat } \\
\text { more likely }\end{array}$ & $\begin{array}{c}\text { Much more } \\
\text { likely }\end{array}$ \\
\hline $\begin{array}{l}\text { Pulse crops reduce } \\
\text { greenhouse gases }\end{array}$ & 0.81 & 1.61 & 31.05 & 38.31 & 28.23 \\
\hline $\begin{array}{l}\text { Pulse crops improve soil } \\
\text { health and reduce the need } \\
\text { for fertilisers }\end{array}$ & 0.81 & 0.40 & 28.23 & 42.34 & 28.23 \\
\hline $\begin{array}{l}\text { Pulse crops contribute to } \\
\text { sustainable agriculture }\end{array}$ & 0.81 & 0.00 & 27.94 & 40.49 & 30.77 \\
\hline $\begin{array}{l}\text { Pulse crop production and } \\
\text { consumption improves our } \\
\text { local economy }\end{array}$ & 0.40 & 1.21 & 25.81 & 42.74 & 29.84 \\
\hline
\end{tabular}

The attitudes revealed in the survey results demonstrate the participants' orientation towards the importance of environmental practices. The participants' academic disciplines were intentionally examined in this study as previous findings suggested that disciplines may influence pro-environmental behaviour (Talay, Gündüz, and Akpinar 2004). It has been suggested that environmental education is directly tied to pro-environmental behaviours (Rodríguez-Barreiro et al. 2013), and although it is not clear whether the participants in the present study had an environmental science or similarly related background, $35 \%$ had an academic discipline in the sciences, suggesting that this group of participants could favour more pro-environmental behaviours. However, this suggestion was not supported by the results of the present study, as having an academic discipline in the sciences was not linked to the amount of pulses consumed $(p=.046)$ or to environmental variables $F(4,242)=.637, p$ $=.637$.

\subsection{Limitations}

A few limitations to this design must be recognised. The primary variables were self-reported; therefore, there is a potential for social desirability bias and response bias. Volunteer bias is also probable. Additionally, as this study only examined students who are enrolled at a single university, it is not representative of the general population, and results may not be generalisable to university students across Canada. Although there are a number of limitations, providing participants with an incentive to complete the survey likely helped to improve the response rate, which most likely resulted in a larger and more diverse sample. 


\section{Conclusion}

The importance of understanding the attitudes of university students towards pulse crops' impact on the environment and of finding ways to influence this behaviour through education is critical to create a positive change in consumption habits. These results could be used to create age-targeted educational campaigns focusing on addressing the misconceptions or lack of knowledge of pulse crops. Additionally, targeted labelling on food products to highlight their environmental benefits is another way to have these benefits showcased, as $69 \%$ of participants reported that they looked at nutritional labels, and $68 \%$ advocated for the protection and responsible use of the natural environment. Using simple language, packaging could state that the products are "Locally grown" or "Grown in Canada" to entice Canadian consumers to purchase pulses as many students are concerned about buying foods that are grown locally as an attempt to reduce their carbon footprints and support the local economy.

Given that $71 \%$ of the present study's participants indicated that it is important to eat locally grown foods and 39\% indicated that environmentally sustainable agricultural practices influenced their food purchases, if pulse food packaging showcased that pulse crops can contribute to sustainable agriculture and support the local economy then consumers may have more incentives to purchase them.

The hope is that results from this study can further help to aid in informing efforts to increase pulse consumption, which could support efforts to the solution of sustainable land use and environmentally conscious practices in Canada.

\section{Acknowledgement}

P. Kellett and E. Pijl are acknowledged for their assistance with this research.

\section{References}

Angadi, S. V., McConkey, B. G., Cutforth, H. W., Miller, P. R., Ulrich, D., Selles, F., ... $\&$ Brandt, S. A. (2008). Adaptation of alternative pulse and oilseed crops to the semiarid Canadian Prairie: Seed yield and water use efficiency. Canadian Journal of Plant Science, 88, 425-438. https://doi.org/10.4141/CJPS07078

Boye, J., Zare, F., \& Pletch, A. (2010). Pulse proteins: processing, characterization, functional properties and applications in food and feed. Food Research International, 43, 414-431. https://doi.org/10.1016/j.foodres.2009.09.003

Carlyle, W. J. (2004). The rise of specialty crops in Saskatchewan, 1981-2001. Canadian Geographer, 48(2), 137-151. https://doi.org/10.1111/j.0008-3658.2004.00052.x

Cortes, P. L., Dias, A. G., Fernandes, M. E. D. S. T., \& Pamplona, J. M. V. (2016). Environmental behavior: A comparative study between Brazilian and Portuguese students. Ambiente \& Sociedade, 19(3), 113-134.

https://doi.org/10.1590/1809-4422ASOC139099V1932016

Froehlich, C. A., Leis, A., Humbert, M. L., Engler, S. R., \& Muhajarine, N. (2015). Supporting healthy eating among rural early years children: A pulse crop pilot intervention 
study. Journal of Agromedicine, 20(3), 386-389.

https://doi.org/10.1080/1059924X.2015.1046624

Gan, Y., Hamel, C., Kutcher, R., \& Poppy, L. (2017). Lentil enhances agroecosystem productivity with increased residual soil water and nitrogen. Renewable Agriculture and Food Systems, 32(4), 319-330. https://doi.org/10.1017/S1742170516000223

Gan, Y., Liang, C., Wang, X., \& McConkey, B. (2011). Lowering carbon footprint of durum wheat by diversifying cropping systems. Field Crops Research, 122, 199-206. https://doi.org/10.1016/j.fcr.2011.03.020

Health Canada. n.d. Canadian Nutrient File $(C N F)$. Retrieved from https://food-nutrition.canada.ca/cnf-fce/index-eng.jsp.

Ipsos, R. (2010). Factors influencing pulse consumption in Canada. Final Report. Retrieved from

http://www1.agric.gov.ab.ca/\$Department/deptdocs.nsf/all/sis13117/\$FILE/v3_factors_influe ncing_pulse_consumption_final_report_feb24_2010.pdf

Jensen, E. S., Peoples, M. B., Boddey, R. M., Gresshoff, P. M., Hauggaard-Nielsen, H., Alves, B. J. R., \& Morrison, M. J. (2012). Legumes for mitigation of climate change and the provision of feedstock for biofuels and biorefineries. A review. Agronomy for Sustainable Development, 32(1), 329-364. https://doi.org/10.1007/s13593-011-0056-7

Lemke, R. L., Zhong, Z., Campbell, C. A., \& Zentner, R. (2007). Can pulse crops play a role in mitigating greenhouse gases from North American agriculture? Agronomy Journal, 99(6), 1719-1725. https://doi.org/10.2134/agronj2006.0327s

Miller, P. R., McConkey, B. G., Clayton, G. W., Brandt, S. A., Staricka, J. A., Johnson, G. P. A., .. \& Neill, K. E. (2002). Pulse crop adaptation in the Northern Great Plains. Agronomy Journal, 94(2), 261-272. https://doi.org/10.2134/agronj2002.0261

Phillips, T., Zello, G. A., Chilibeck, P. D., \& Vandenberg, A. (2015). Perceived benefits and barriers surrounding lentil consumption in families with young children. Canadian Journal of Dietetic Practice and Research, 76 (1), 3-9. https://doi.org/10.3148/cjdpr-2014-025

Pimentel, D., \& Pimentel, M. (2003). Sustainability of meat-based and plant-based diets and the environment. American Journal of Clinical Nutrition, 78(3), 660S-663S. https://doi.org/10.1093/ajcn/78.3.660S

Pulse Canada. n.d. Pulse nutrition information. Retrieved from http://pulsecanada.clickonce.ca/site_customs/nutrition.

Ramdath, D., Renwick, S., \& Duncan, A. M. (2016). The role of pulses in the dietary management of diabetes. Canadian Journal of Diabetes, 40, 355-363.

https://doi.org/10.1016/j.jcjd.2016.05.015

Rodríguez-Barreiro, L. M., Fernández-Manzanal, R., Serra, L. M., Carrasquer, J., Murillo, M. B., Morales, M. J., ... \& Valle, J. del (2013). Approach to a causal model between attitudes 


\section{Macrothink}

Journal of Agricultural Studies

ISSN 2166-0379 2018, Vol. 6, No. 3

and environmental behaviour: A graduate case study. Journal of Cleaner Production, 48, 116-125. https://doi.org/10.1016/j.jclepro.2012.09.029

Talay, I., Gündüz, S., \& Akpinar, N. (2004). On the status of environmental education and awareness of undergraduate students at Ankara University, Turkey. International Journal of Environmental Pollution, 21(3), 293-308.

Tilman, D., \& Clark, M. (2014). Global diets link environmental sustainability and human health. Nature, 515, 518-522. https://doi.org/10.1038/nature13959

Tosh, S. M., \& Yada, S. (2010). Dietary fibres in pulse seeds and fractions: characterization, functional attributes, and applications. Food Research International, 43, 450-460. https://doi.org/10.1016/j.foodres.2009.09.005

University of Lethbridge. (2017). Fall 2017. Retrieved from http://www.uleth.ca/analysis/content/view-facts.

\section{Copyright Disclaimer}

Copyright for this article is retained by the author(s), with first publication rights granted to the journal.

This is an open-access article distributed under the terms and conditions of the Creative Commons Attribution license (http://creativecommons.org/licenses/by/4.0/). 